\title{
INVOLVEMENT OF ETHYLENE SYNTHETIC INHIBITORS IN REGULATING THE SENESCENCE OF CUT CARNATIONS THROUGH MEMBRANE INTEGRITY MAINTENANCE
}

\author{
Fahmy HASSAN*1,2, Esmat ALI ${ }^{1,3}$, Ragia MAZROU ${ }^{4}$ \\ ${ }^{1}$ Biology Department, Faculty of Science, Taif University, Saudi Arabia \\ ${ }^{2}$ Horticulture Department, Faculty of Agriculture, Tanta University, Egypt \\ ${ }^{3}$ Horticulture Department, Faculty of Agriculture, Assuit University, Egypt \\ ${ }^{4}$ Horticulture Department, Faculty of Agriculture, Menoufia University, Egypt
}

Received: January 2020; Accepted: May 2020

\begin{abstract}
Postharvest senescence is a critical problem of carnation cut flowers, limiting their transportation and subsequent marketing chain. This study was designed to assess whether the application of 1-methylcyclopropene (1-MCP), silver nanoparticles (AgNPs), and nitric oxide (NO) released from donor sodium nitroprusside (SNP) could prolong the vase life of cut carnations through an influence on the physiological and biochemical mechanisms involved in aging process. 1-MCP was used in the concentrations of $0,100,200$, and $300 \mathrm{mg} \cdot \mathrm{m}^{-3}$; AgNPs in the concentrations of $0,50,100$, and $150 \mathrm{mg} \cdot \mathrm{dm}^{-3}$; and SNP in the concentrations of $0,0.1,0.2,0.3$, and $0.4 \mathrm{mM}$. All treatments significantly extended the cut flower life compared with untreated flowers, more so with $300 \mathrm{mg} \cdot \mathrm{m}^{-3}$ of $1-\mathrm{MCP}, 100 \mathrm{mg} \cdot \mathrm{dm}^{-3}$ of AgNPs, or $0.3 \mathrm{mM}$ of SNP. All these chemical compounds were able to considerably improve the relative water content (RWC), reduce the malondialdehyde (MDA) content and increase the membrane stability index (MSI) in petals and, therefore, maintain the membrane integrity. In addition, they decreased the activities of acetyl-CoA synthetase (ACS) and nitric oxide synthase (NOS) and, hence, depressed the production of ethylene in carnation cut flowers through downregulating the ethylene production, what prolonged the vase life. Altogether, the application of exogenous 1-MCP, AgNPs, or SNP may provide a promising avenue to improve the postharvest performance of carnation cut flowers.
\end{abstract}

Keywords: Flower senescence, ethylene, vase life, membrane stability, ACS synthase

\section{INTRODUCTION}

The major factor that limits the marketing of various cut flower species is postharvest senescence; therefore, considerable attention has been dedicated to introduce modern postharvest treatments for extending the period of marketing (Bowyer et al. 2003). Providing valuable information for floriculture industry that allows the consumers to obtain attractive flowers with higher longevity is an important goal of researchers who work for the postharvest of cut flowers (Hassan \& Ali 2014). Hence, delaying and controlling the postharvest senescence is a sensible factor for enhancing the flower quality and longevity that lead to acquire high benefit (Hassan \& Schmidt 2004; Terék et al. 2010). However, some missing information has to be appropriately achieved to introduce it as a deputy model for cut flower senescence. Although there are various treatments for extending the cut flower life, the flower senescence process is still not fully understood (In et al. 2013).

Carnation is one of the most economically important cut flowers that plays an important role in the florist trade (Chang-li et al. 2011); however, the major limitation of marketing cut carnations is postharvest senescence (Song et al. 2014). It is well known that the sensitivity of carnation flowers to ethylene is high and its production is highly increased in flowers through senescence (Onozaki et al. 2004). As carnation flower senescence was delayed by the application of ethylene inhibitors, the regulation of senescence by endogenous ethylene suppression was suggested. Pun et al. (2014) reported that the increase in carnation vase life is ascribed to the suppression of ethylene biosynthesis caused by the inhibition of transcription of two enzymes: 1-aminocyclopropane1-carboxylate oxidase (ACO) and 1-aminocyclopropane-1-carboxylase synthase (ACS). 
Several aspects of growth and progression, including flower senescence, are adjusted by ethylene (Reid \& Wu 1992). Some deleterious effects of exposure to ethylene, including leaf yellowing, flower (or petal) drop, irregular opening and premature death, were observed (Nowak \& Rudnicki 1990). Therefore, to develop postharvest treatments leading to the suppression of ethylene production and, hence, extending the flower vase life, it is important to understand the postharvest physiology of cut flowers. Although silver thiosulfate (STS) is the best weapon against ethylene, which suppresses the production of endogenous ethylene and, hence, delays ethylene-sensitive cut flowers senescence (van Doorn et al. 1991), there are some restrictions on the commercial use of STS because of environmental toxicity of heavy metal (Cross 1996). 1-Methylcyclopropene (1-MCP) is a non-toxic ethylene action inhibitor that binds to competitive ethylene receptor (Sisler et al. 1996). Hence, it was found that 1-MCP works effectively in many cut flowers to prolong their postharvest longevity, including carnations, (Sisler et al. 1996; In et al. 2013), gladiolus (Hassan $\&$ Ali 2014), and rose (Liao et al. 2013). There are some reports about the effect of 1-MCP on carnation focused on ethylene synthesis and production. However, reports concerning the changes in biochemical and physiological attributes of carnation cut flowers because of the application of 1-MCP remain limited.

Recently, nanotechnology is vastly used in agriculture to improve the production and reduce postharvest wastage (Mousavi \& Rezaei 2011). Silver nanoparticles (AgNPs) are widely studied nanomaterials, which fascinate researchers because of their unique optical, catalytic, antimicrobial and sensing properties (Sharma et al. 2014). Several authors reported an extension in vase life of cut carnations (Naing et al. 2017; Park et al. 2017; Liu et al. 2018) and other cut flowers (Kim et al. 2005; Hassan et al. 2014; Li et al. 2017) because of the application of AgNPs. However, AgNP treatments were suggested as a biocide rather than an ethylene inhibitor. Therefore, more information is still required on the possible physiological and biochemical mechanisms of AgNPs in improving the longevity of cut carnations.
Nitric oxide (NO) was first noticed in plants by Leshem and Haramaty (1996), and subsequent studies linked its occurrence to a wide range of physiological processes such as vegetative stress and endogenous ethylene modulation (Leshem \& Pinchasov 2000), water loss ( $\mathrm{Ku}$ et al. 2000), and chlorophyll synthesis (Giba et al. 1998). In recent studies, the role of NO in agricultural production, including improving the quality of horticultural products, has gained more attention. NO is considered as a growth-regulating operator that delays senescence through down controlling ethylene emission (Leshem \& Wills 1998). On the other hand, reports concerning further details about the relation between $\mathrm{NO}$ and ethylene during the senescence of cut flowers remain limited. Sodium nitroprusside (SNP) as NO donor was used for improving the longevity of several cut flowers, such as carnation (Chang-li et al. 2011), chrysanthemum (Mansouri 2012), gerbera (Shabanian et al. 2018), and rose (Liao et al. 2013; Deng et al. 2019). Although Badiyan et al. (2004) suggested that NO appears to have widespread applicability to postharvest technology of flowers and offers a simple technology to prolong vase life, the precise function of NO in retarding the senescence in cut flowers is still exactly unknown. In addition, the information about the response of physiological and biochemical processes resulted from exogenous application of NO during the vase life of cut flowers is required. Therefore, the aim of this study was to estimate the optimum levels of 1-MCP, AgNPs, and SNP for maximizing the longevity of cut carnations and to investigate the possible physiological and biochemical mechanisms of senescence connected with the use of above chemical products.

\section{MATERIALS AND METHODS}

\section{Plant materials}

Dianthus caryophyllus 'Barbara' was used in these experiments. The flowers were obtained from a greenhouse of commercial grower in a stage when the outer petals became perpendicular to the stem axis. The flowers were immediately placed in buckets contained tap water and directly transported to the laboratory where flower stems were re-cut under distilled water to a 40-cm length and treated with 1MCP, AgNPs, and NO. 


\section{Searching for optimal concentration (Exp. 1)}

$1-\mathrm{MCP}$ was diluted in distilled water according to manufacturer's instructions (Ethyl Block, Rohm and Haas Italy, Inc.). In each treatment, carnation flowers were placed in a sealed container in a solution of $1-\mathrm{MCP}$ at the concentrations of $0,100,200$, and $300 \mathrm{mg} \cdot \mathrm{m}^{-3}$ for $6 \mathrm{~h}$ and incubated at $15^{\circ} \mathrm{C}$. After the treatments, flowers were aerated. AgNP (Shanghai Huzheng Nano Technology Co. Ltd., China) was dissolved in double distilled water and applied in concentrations of $0,50,100$, and $150 \mathrm{mg} \cdot \mathrm{dm}^{-3}$. SNP was used as NO donor in the concentrations of $0,0.1,0.2$, 0.3 , and $0.4 \mathrm{mM}$. In the solutions of these preparations, the ends of the shoots stayed for 24 hours. After the treatment, flowers were transferred into conical flasks with distilled water to evaluate the flower longevity. Plastic film was used to cover the mouths of conical flasks of evaluated flowers to reduce evaporation and prohibit contamination (Li et al. 2012).

\section{Vase life evaluation}

Cut carnations longevity was evaluated at $20{ }^{\circ} \mathrm{C} \pm$ $2{ }^{\circ} \mathrm{C}$ at a relative humidity of $65 \% \pm 5 \%$ and 12 -h photoperiod with $10-12 \mu \mathrm{mol} \cdot \mathrm{m}^{-2} \cdot \mathrm{s}^{-1}$ irradiance from cool-white fluorescence lamps. The cut flowers were assessed daily through the whole period. Vase life was defined as the number of days from the beginning of the experiment to the time when $50 \%$ of flowers wilted or lost a decorative value. Five replicates of five flowers each were used for each treatment.

Evaluation of the physio-biochemical responses of cut carnations to 1-MCP, AgNPs, and NO (Exp. 2)

This experiment was designed based on the data obtained from the first experiment using most effective concentrations.

\section{Relative water content}

Petal relative water content (RWC) was assessed as reported by Weatherley (1950) using the following formula: $\left(\mathrm{W}_{\text {fresh }}-\mathrm{W}_{\text {dry }}\right) /\left(\mathrm{W}_{\text {turgid }}-\mathrm{W}_{\text {dry }}\right) \times 100$, where $\mathrm{W}_{\text {fresh }}$ is the sample fresh weight, $\mathrm{W}_{\text {turgid }}$ is the sample turgid weight after being saturated with distilled water for $24 \mathrm{~h}$ at $4{ }^{\circ} \mathrm{C}$ and $\mathrm{W}_{\text {dry }}$ is the weight of samples oven dried at $70{ }^{\circ} \mathrm{C}$ for $48 \mathrm{~h}$. Petal samples were collected on days $0,1,2,4,6$, and 8 from the beginning of the experiment.

\section{Petal lipid peroxidation}

Lipid peroxidation levels in tissues were assessed spectrophotometrically (Pharmacia, LKB-Novaspec II) by malondialdehyde (MDA) determination as described by Hodges et al. (1999) at days 0, 1, 2, 4, 6 and 8 . MDA levels were estimated using the following formula: $\mathrm{MDA}$ content $=6.45 \times\left(\mathrm{A}_{532}-\mathrm{A}_{600}\right)-$ $0.56 \times \mathrm{A}_{450}$, where $\mathrm{A}_{450}, \mathrm{~A}_{532}$, and $\mathrm{A}_{600}$ are the $\mathrm{ab}$ sorbance at 450,532 , and $600 \mathrm{~nm}$, respectively, and were expressed in $\mu \mathrm{mol} \cdot \mathrm{ml}^{-1}$.

\section{Membrane stability index}

Ions leakage of petal samples taken on days $0,1,2,4$, 6 and 8 were determined using the method of Sairam et al. (1997). Briefly, two samples $(0.2 \mathrm{~g})$ were placed in $20 \mathrm{ml}$ of double distilled water in two different 50 -ml flasks. The first one $\left(\mathrm{C}_{1}\right)$ was kept at $40{ }^{\circ} \mathrm{C}$ for 30 min, whereas the second $\left(\mathrm{C}_{2}\right)$ was kept at $100{ }^{\circ} \mathrm{C}$ in boiling water bath for $15 \mathrm{~min}$. The electric conductivity was measured with a conductivity meter (Jenway 3540). The ions leakage was expressed as the membrane stability index (MSI) as given in the following formula: $\mathrm{MSI}=\left[1-\left(\mathrm{C}_{1} / \mathrm{C}_{2}\right)\right] \times 100$.

\section{Determination of ethylene concentration}

Flower samples were placed and sealed in 100-ml air tight glass vessels fitted with gas sampling ports. The vessels were kept at $20^{\circ} \mathrm{C}$ and at $60-70 \% \mathrm{RH}$ for $2 \mathrm{~h}$. Gas samples $(1 \mathrm{ml})$ were withdrawn from the headspace of vessels for the evaluation of ethylene. Samples were collected on days $0,1,2,4,6$, and 8. Gas chromatography was used according to Heiser et al. (1998) and the previously mentioned method of Hassan and Mahfouz (2012) using a Varian GC CP-3800 and MS Saturn 2200. The values of ethylene were recorded as $\mathrm{nl}^{-\mathrm{g}^{-1}} \mathrm{FW} \mathrm{h} \mathrm{h}^{-1}$.

\section{Petal ACS and NOS activities}

For the analysis of 1-aminocyclopropane-1-carboxylic acid synthase (ACS), petals $(0.5 \mathrm{~g})$ were extracted as described by Ichimura et al. (2009). The activity of ACS was assessed by incubating a standard reaction mixture containing $0.4 \mathrm{ml}$ of enzyme preparation and $0.1 \mathrm{ml}$ each of $4 \mathrm{mM}$ HEPES-KOH ( $\mathrm{pH}$ 8.5), $0.3 \mathrm{mM}$ S-adenosylmethionine, and $0.4 \mu \mathrm{M}$ pyridoxal 5 -phosphate at $30^{\circ} \mathrm{C}$ for $30 \mathrm{~min}$ and the reaction was stopped by adding $0.1 \mathrm{ml}$ of $20 \mathrm{mM} \mathrm{HgCl}_{2}$. The activity of ACS was measured as $\mathrm{nmol} \cdot \mathrm{g}^{-1} \mathrm{FW} \mathrm{h}{ }^{-1}$. The activity of NOS was evaluated according to Murphy and Noack (1994) with some modifications. Fresh petal samples $(2 \mathrm{~g})$ were homogenized in $5 \mathrm{ml}$ of homogenization buffer $(50 \mathrm{mM}$ triethanolamine hydrochloride, $\mathrm{pH} 7.5$, containing $0.5 \mathrm{mM}$ ethylenediaminetetraacetic acid (EDTA), 
$1 \mu \mathrm{M}$ leupeptin, $1 \mu \mathrm{M}$ pepstatin, $7 \mathrm{mM}$ of glutathione, and $0.2 \mathrm{mM}$ phenylethylsulfonyl fluoride). After centrifugation at $10,000 \times \mathrm{g}$ for $20 \mathrm{~min}$, the supernatant was collected and re-centrifuged at $100,000 \times \mathrm{g}$ for $45 \mathrm{~min}$ at $4{ }^{\circ} \mathrm{C}$. NOS activity in the supernatant was assessed by a hemoglobin assay and expressed as $\mathrm{pmol} \cdot \mathrm{min}^{-1} \mu \mathrm{g}^{-1}$ protein.

The experimental design and statistical analysis Treatments were arranged in a complete randomized design with five replicates with five flowers each. The experiment was repeated three times during March to May 2017, and the results were pooled $(\mathrm{n}=15)$. The ANOVA was performed, and the results were analyzed using SPSS 13.3 program, and means were compared by Tukey-Kramer's multiple range test at $p=0.05$.

\section{RESULTS}

\section{Flower longevity}

All applied chemicals significantly enhanced the longevity of carnation flowers relative to untreated control (Table 1, Fig. 1). Using 1-MCP, the longest vase life was recorded by applying $200 \mathrm{mg} \cdot \mathrm{m}^{-3}$, what was about 2 times higher than in the control. The vase life was significantly extended because of AgNP treatments in comparison with the control. The longest life was obtained using the moderate level $\left(100 \mathrm{mg} \cdot \mathrm{dm}^{-3}\right)$ that increased the vase life by 1.8-fold compared with the control. SNP concentration of $0.3 \mathrm{mM}$ maximized the flower life that was 2.3-fold of untreated flowers (Table 1).

\section{Relative water content}

The RWC of carnation petals treated with 1-MCP, AgNPs, and SNP is shown in Fig. 2. All treatments significantly enhanced RWC relative to the untreated flowers, especially from day 2 . The RWC of all treatments resulted in the trend toward increasing till day 4 and in the treatments with 1-MCP and SNP further increased till day 6 but then decreased. However, in flowers treated with AgNPs and untreated flowers, the RWC increased till day 4 and then sharply decreased, especially in control. The maximum RWC was recorded by the application of SNP followed by 1 -MCP without significant differences $(\mathrm{p} \leq 0.05)$ but still higher than AgNPs over the vase life period.

Table 1. Longevity of carnation cut flowers pretreated with 1-methylcyclopropene (1-MCP), silver nanoparticle $(\mathrm{AgNP})$, and sodium nitroprusside $(\mathrm{SNP})$. Data are means $\pm \mathrm{SE}(\mathrm{n}=15)$. Values with different letters are statistically significant according to Tukey-Kramer's multiple range test at 0.05 level

\begin{tabular}{|c|c|c|c|c|c|}
\hline $\begin{array}{c}1-\mathrm{MCP} \\
\text { treatments } \\
\left(\mathrm{mg} \cdot \mathrm{m}^{-3}\right)\end{array}$ & $\begin{array}{l}\text { Vase life (days) and } \\
\text { relative increment } \\
(\%)\end{array}$ & $\begin{array}{l}\text { AgNPs } \\
\text { treatments } \\
\left(\mathrm{mg} \cdot \mathrm{dm}^{-3}\right)\end{array}$ & $\begin{array}{l}\text { Vase life (days) and } \\
\text { relative increment } \\
(\%)\end{array}$ & $\begin{array}{l}\text { SNP } \\
(\mathrm{mM})\end{array}$ & $\begin{array}{l}\text { Vase life (days) and } \\
\text { relative increment } \\
(\%)\end{array}$ \\
\hline Control & $6.5 \pm 0.6 \mathrm{~d}(100)$ & Control & $6.6 \pm 0.9 c(100)$ & Control & $6.8 \pm 0.8 \mathrm{~d}(100)$ \\
\hline 100 & $9.4 \pm 0.9 \mathrm{c}(145)$ & 50 & $9.0 \pm 0.7 b(135)$ & 0.1 & $9.3 \pm 0.6 \mathrm{c}(136)$ \\
\hline 200 & $13.1 \pm 0.4 \mathrm{a}(203)$ & 100 & $12.1 \pm 1.1 \mathrm{a}(182)$ & 0.2 & $12.1 \pm 0.9 b(177)$ \\
\hline \multirow[t]{2}{*}{300} & $11.9 \pm 0.5 b(184)$ & 150 & $11.5 \pm 0.8 \mathrm{a}(173)$ & 0.3 & $15.9 \pm 1.3 \mathrm{a}(233)$ \\
\hline & & & & 0.4 & $14.2 \pm 0.9 \mathrm{a}(208)$ \\
\hline
\end{tabular}
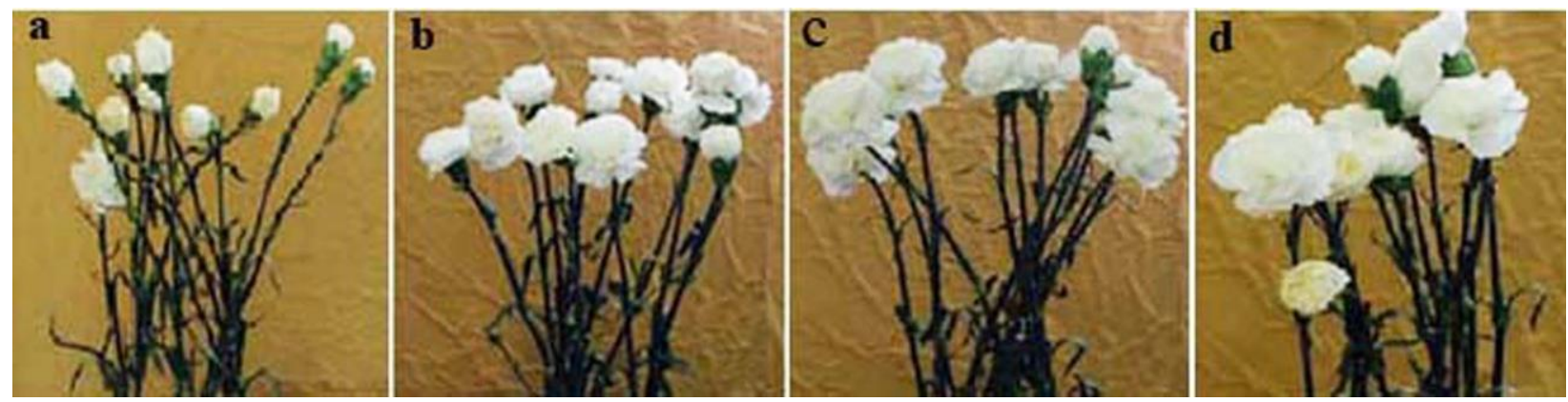

Fig. 1. The impact of SNP (b), 1-MCP (c), and AgNPs (d) on the postharvest quality of cut carnation compared with the control (a). Photo was taken at 6th day after treatment 


\section{Lipid peroxidation (MDA content)}

The content of MDA in untreated flowers showed a considerable increase through the evaluation period and recorded the highest value at day 4. However, 1-MCP, AgNP, and SNP treatments significantly reduced the MDA accumulation compared with untreated control (Fig. 3A). The largest MDA reduction was observed in flowers treated with SNP in comparison with 1-MCP and AgNP treatments. At day 4, the reduction percentage in MDA concentration relative to the control was $40.8 \%, 53.2 \%$, and $58.7 \%$ by applying 1-MCP, AgNPs, and SNP, respectively.

\section{Membrane stability index}

The electrolyte leakage was measured in control and treated flowers in order to assess the membrane stability of carnation petal tissues after harvest. The MSI was found to be higher in flowers treated with 1-MCP, AgNPs, and SNP relative to the control (Fig. 3B). All treatments considerably retained the membrane stability; however, control flowers lost it through the evaluation period. The highest MSI (lowest electrolyte leakage) was observed when SNP treatment was applied followed by AgNPs and 1-MCP. After day 4, the differences between AgNP and $1-\mathrm{MCP}$ treatments were significant $(\mathrm{p} \leq 0.05)$. 1-MCP, AgNP, and SNP treatments could significantly increase the MSI by $23.4 \%, 26.5 \%$, and $28.7 \%$ on day 4 , respectively, compared with the control.

\section{Ethylene production}

To illustrate the relationship between carnation flower senescence and ethylene biosynthesis, ethylene production was determined. Ethylene production in control flowers dramatically increased to day 6 and then decreased sharply (Fig. 4). Otherwise, a significant reduction $(\mathrm{p} \leq 0.05)$ in ethylene production was observed by the application of 1-MCP, AgNPs, and SNP compared with untreated flowers during the evaluation period (Fig. 4). All treatments minimized the ethylene peak value to day 6 , being significantly lower $(\mathrm{p} \leq 0.05)$ than that of the control. The lowest ethylene production was detected in flowers treated with AgNPs.

\section{ACS enzyme activity}

The effects of application of 1-MCP, AgNPs, and SNP on the activity of ACS were analyzed in order to understand and explain the relation between carnation senescence and ethylene biosynthesis.

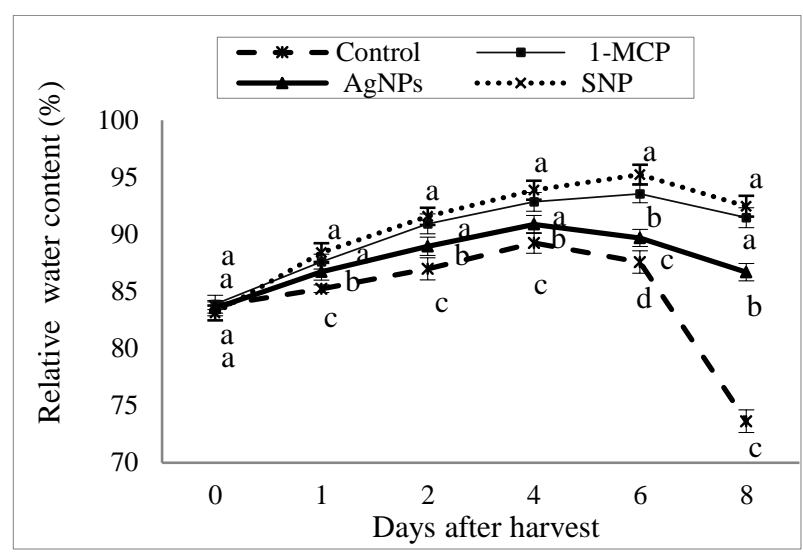

Fig. 2. Effects of 1-methylcyclopropene (1-MCP) at $200 \mathrm{mg} \cdot \mathrm{m}^{-3}$, silver nanoparticles (AgNPs) at $100 \mathrm{mg} \cdot \mathrm{dm}^{-3}$ and sodium nitroprusside (SNP) at $0.3 \mathrm{mM}$ on relative water content (in \%) of carnation cut flowers over vase life period. Values are means $\pm \mathrm{SE}(\mathrm{n}=15)$. Letters represent statistical differences among treatments at each vase life day at $5 \%$ probability.

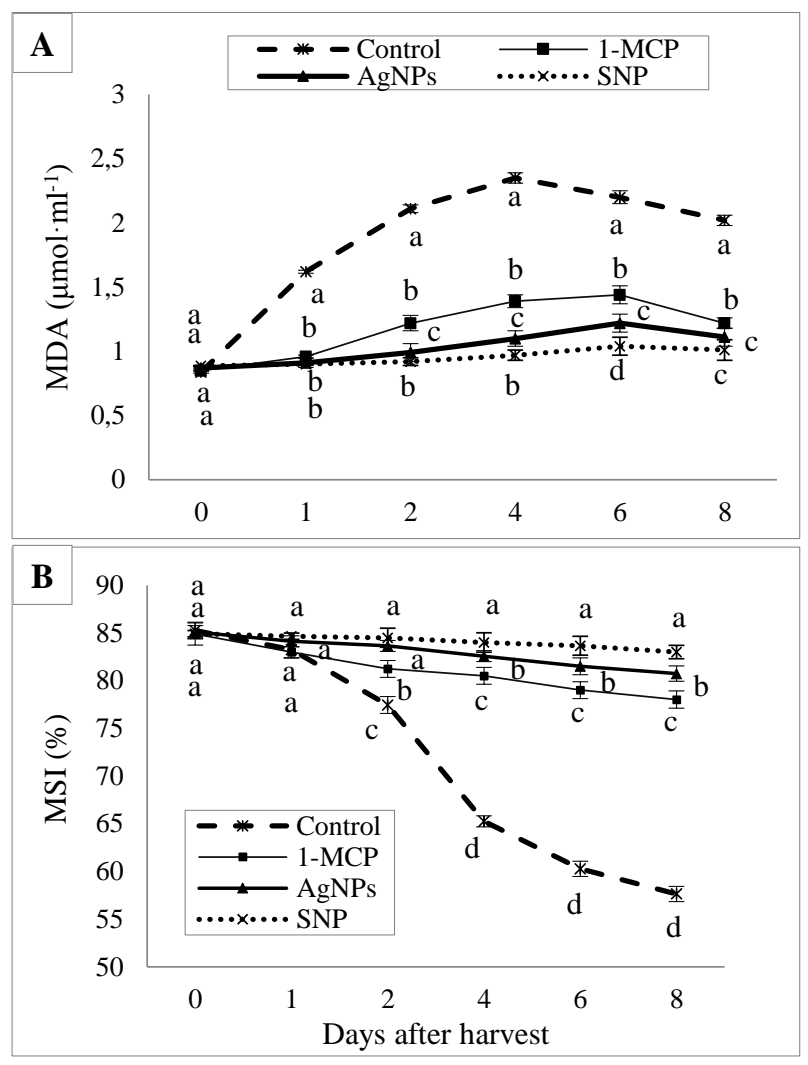

Fig. 3. Effects of 1-methylcyclopropene (1-MCP) at $200 \mathrm{mg} \cdot \mathrm{m}^{-3}$, silver nanoparticles (AgNPs) at $100 \mathrm{mg} \cdot \mathrm{dm}^{-3}$ and sodium nitroprusside (SNP) at $0.3 \mathrm{mM}$ on MDA content $\left(\mu \mathrm{mol} \cdot \mathrm{ml}^{-1}\right)$ and MSI $(\%)$ of carnation cut flowers over vase life period. Values are means $\pm \operatorname{SE}(n=15)$. Letters represent statistical differences among treatments at each vase life day at $5 \%$ probability. 


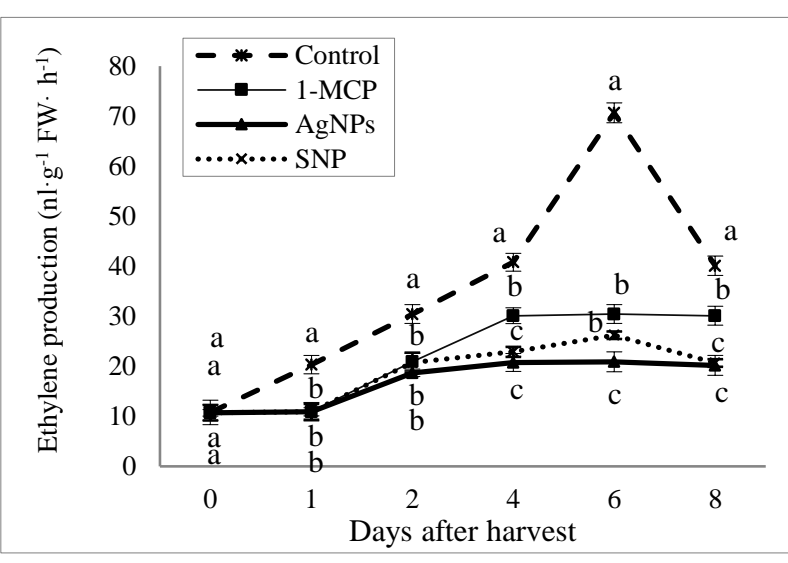

Fig. 4. Effects of 1-methylcyclopropene (1-MCP) at $200 \mathrm{mg} \cdot \mathrm{m}^{-3}$, silver nanoparticles (AgNPs) at $100 \mathrm{mg} \cdot \mathrm{dm}^{-3}$ and sodium nitroprusside (SNP) at $0.3 \mathrm{mM}$ on ethylene production $\left(\mathrm{nl} \cdot \mathrm{g}^{-1} \mathrm{FW} \cdot \mathrm{h}^{-1}\right)$ of carnation cut flowers over vase life period. Values are means $\pm \operatorname{SE}(n=15)$. Letters represent statistical differences among treatments at each life day at $5 \%$ probability.
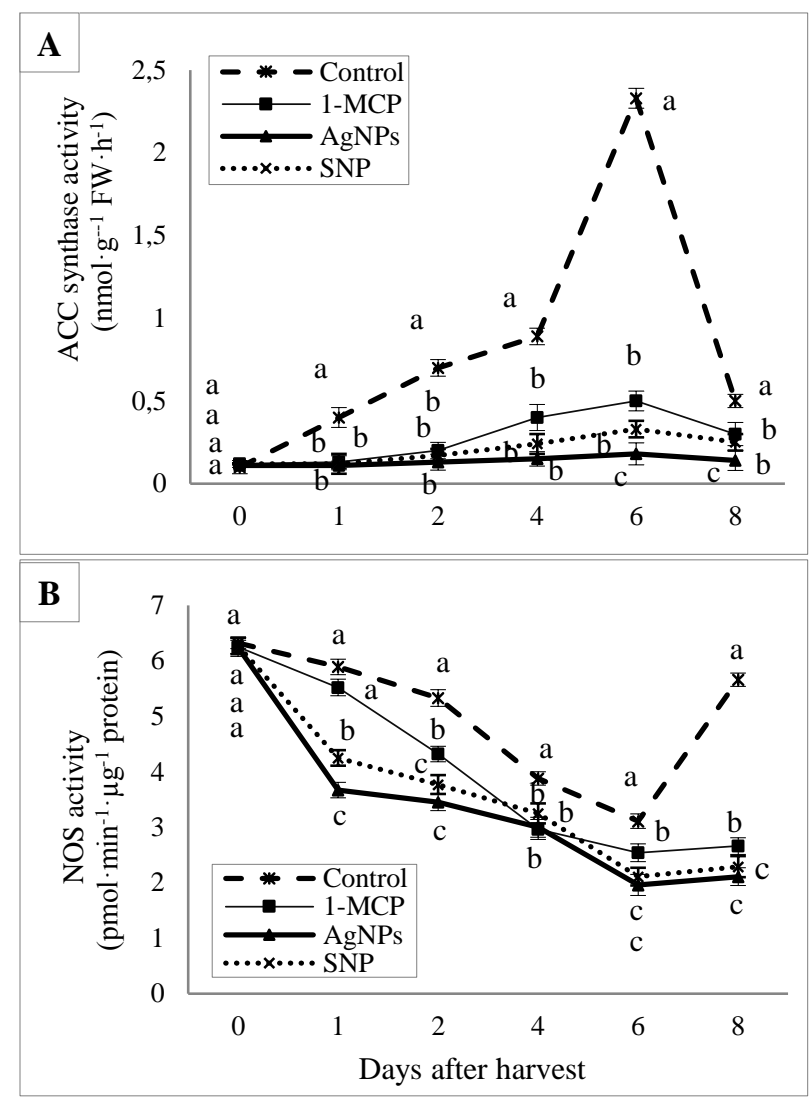

Fig. 5. Effects of 1-methylcyclopropene (1-MCP) at $200 \mathrm{mg} \cdot \mathrm{m}^{-3}$, silver nanoparticles (AgNPs) at $100 \mathrm{mg} \cdot \mathrm{dm}^{-3}$ and sodium nitroprusside (SNP) at $0.3 \mathrm{mM}$ on ACS activity $\left(\mathrm{nmol} \cdot \mathrm{g}^{-1} \mathrm{FW} \cdot \mathrm{h}^{-1}\right)$ and NOS activity $\left(\mathrm{pmol} \cdot \mathrm{min}^{-1} \cdot \mu \mathrm{g}^{-1}\right.$ protein $)$ of carnation cut flowers over vase life period. Values are means $\pm \operatorname{SE}(n=15)$. Letters represent statistical differences among treatments at each vase life day at $5 \%$ probability.
As presented in Fig. 5A, a sharp increase in the activity of ACS was recorded in untreated flowers and reached the peak value on day 6 and decreased thereafter. However, flowers treated with 1-MCP, AgNPs, or SNP recorded significantly lower activities of ACS relative to the untreated flowers during the assessment period.

\section{NOS enzyme activity}

A continuous decrease in the activity of NOS was detected in treated and untreated flowers at the beginning of the assessment period till day 6 and then increased. This reduction was significantly higher in flowers treated with 1-MCP, AgNPs, and SNP compared with the control (Fig. 5B). During the first 2 days, a sharp decrease was observed because of the application of AgNPs and SNP, which was significant compared with the control or 1-MCP treatment. Otherwise, from day 4, the differences among 1-MCP, AgNP, and SNP treatments were insignificant, while still significant relative to the control.

\section{DISCUSSION}

The cut flower senescence is generally continuous and rapid process leading to limiting shelf life. Therefore, in order to gain commercial benefits, the utmost important issue is how to delay the senescence after harvest. One of the important factors that adversely affect the longevity of the cut flower is phytohormone ethylene that may be implicated in flower senescence, assorting senescence pathways and controlling floral abscission (Shahri \& Tahir 2011). The results obtained from the current study clearly show the importance of 1-MCP, AgNPs, and SNP in increasing the longevity of cut carnations by delaying the petal curling during the assessment period. The untreated flowers lost the market value after 6 days; however, flowers treated with 1-MCP, AgNPs, and SNP lost it after 13, 12, and 15 days, respectively, because of dehydration of flower margins and appearance of browning. Sisler et al. (1996) reported that $1-\mathrm{MCP}$ is an ethylene action inhibitor that acts competitively and irreversibly in blocking the ethylene receptor and, hence, inhibits the flower senescence. Prolonging the cut flower life as a result of the application of 1-MCP has been documented (In et al. 2013; Liao et al. 2013; Hassan \& Ali 2014). 
As reported, the application of AgNPs caused ethylene inhibition (Kim et al. 2005). In our experiment, AgNP treatment significantly extended the carnation vase life relative to the control. These results are in accordance with the reports of Rafi and Ramezanian (2013) and Hassan et al. (2014) on cut roses. In our study, SNP that was used as the source of NO also extended carnation vase life compared with untreated flowers. NO considerably extends the cut flowers life by inhibiting the ethylene emission, suggesting that NO might play important functions in senescence regulation process (Leshem \& Wills 1998). In addition, Liao et al. (2013) concluded that NO might perform as a signal molecule in cut rose senescence stimulated by ethylene. Our data support the previous findings of Zeng et al. (2011) on carnation and Mansouri (2012) on chrysanthemum.

The current results show that prolonging the flower vase life was correlated with increasing the RWC in petals that was significantly improved because of all three treatments compared with untreated control. Indeed, reverse water relation led to petal wilting and terminated the cut flower life (Hassan \& Schmidt 2004; Hassan et al. 2014). Carnation flowers treated with 1-MCP maintained the RWC significantly higher relative to the untreated flowers; therefore, this treatment may increase the uptake or maintain the water in flowers. Such an increase in RWC as a result of 1-MCP has been observed by Hassan and Ali (2014). The increase in RWC because of the AgNP treatment may be ascribed to the repression of stomatal aperture and conductance, hence, maintaining the water balance (Rafi \& Ramezanian 2013; Hassan et al. 2014). The application of SNP increased the RWC of cut carnations as well. Zeng et al. (2011) who worked on carnation and Mansouri (2012) on chrysanthemum reported an increase in the fresh mass of cut flowers because of balanced water metabolism connected with the increased ability to water uptake.

In view of our results, the flower senescence in carnation may be regulated by 1-MCP, AgNPs, or SNP that resulted in maintaining the membrane stability and reducing lipid peroxidation. During the flower vase life, 1-MCP, AgNP, and SNP treatments increased the MSI and reduced the accumulation of MDA compared with untreated flowers (Hassan \& Fetouh 2019; Hassan et al. 2020). The lipid peroxidation reduction and maintenance of the membrane stability have been elucidated to be reversely proportional with cut flower senescence (Hassan \& Ali 2014; Ali et al. 2018). Therefore, our results suggested the participation of lipid peroxidation reduction in increasing the MSI in cut carnations because of the application of 1-MCP, AgNPs, and SNP. Mitigation of cut flower senescence by reducing lipid peroxidation has been documented in response to the treatments of 1-MCP (Hassan \& Ali 2014), AgNPs (Hassan et al. 2014), and NO (Zeng et al. 2011; Mansouri 2012; Shabanian et al. 2018). In addition, it was found that SNP treatment may directly protects the membranes and lipoproteins from oxidation, mainly by interacting with lipid peroxyl radicals, or indirectly by the inhibiting the activity of lipoxygenase (Beligni et al. 2002).

The production of ethylene by carnation flowers was significantly reduced when flowers were treated with 1-MCP, AgNPs, or SNP in comparison with untreated control. Our results were in accordance with In et al. (2013), Liao et al. (2013), and Hassan and Ali (2014). Recently, considerable interest has been driven towards NO because it has a critical role in both plant growth and development as a signal molecule (Corpas et al. 2006). Interestingly, NO action could considerably inhibit the ethylene emission and consequently extend the shelf life of flowers and fruits (Leshem \& Wills 1998). Moreover, NO might delay the flower senescence by reducing the ethylene production through suppressing the activity of ACC synthase, and decreasing the ACC content (Zhu \& Zhou 2007). There is evidence that NO significantly and reversibly inhibits cytochrome oxidase and inhibits both the cell respiration and ethylene accumulation (Zottini et al. 2002). These results further confirmed the other reports of Liao et al. (2013) and Zeng et al. (2011) who concluded that NO reduced the ethylene production by cut flowers. Otherwise, decreasing ethylene production by 1 -MCP, AgNPs, and SNP in our study may explain the increase in flower life after treatment, suggesting that NO might have substantial roles in controlling the flower senescence in cut carnations. 
This study also showed that carnation flowers treated with 1-MCP, AgNPs, or SNP resulted in lower activities of ACS and NOS compared with untreated control what suggests that the decrease in ethylene production is caused by the suppression of the activity of ACS. Eum et al. (2009) observed that the application of NO delayed the senescence of postharvest in some horticultural products through inhibiting both ethylene sensitivity and its production. Moreover, Mortazavi et al. (2011) reported that the ethylene output was decreased in cut roses treated with NO by inhibiting the activity of ACS and decreasing ACC content. The inhibition of ACS has been found to be an evidence to explain the mode of action of NO (Zaharah \& Singh 2011).

In control flowers, the higher activity of NOS in day 8 may be ascribed to the reduction in ethylene produced by flowers in that day, which is caused by the inhibition in ACS observed in the same day. Our findings proposed that retarding the cut carnation senescence as a result of the presence of NO is caused in part by reducing the activity of ACS and, hence, ethylene production. The current findings are consistent with others of Liao et al. (2013) who found that cut roses treated with NO exhibited the lower level of ACC activity that led to the reduction of ethylene production. On the basis of our results, 1-MCP and AgNP treatments also reduced the activity of NOS and ACS and consequently decreased the ethylene production, prolonging carnation vase life through downregulating the production of ethylene. To our knowledge, the relation between AgNPs and the activity of NOS suggested in this study is a novel. Our results revealed that 1-MCP, AgNPs, or NO may impair ethylene signaling levels during carnation cut flower senescence.

In conclusion, the application of 1-MCP, AgNPs, or SNP considerably increased carnation 'Barbara' vase life. All treatments reduced lipid peroxidation, hence, maintained the cell membrane integrity that is associated with the vase life extension. Suppressing the activities of ACS and NOS in treated flowers resulted in decreasing ethylene production, which is an important factor in retarding senescence of sensitive flowers such as carnation.

\section{REFERENCES}

Ali E.F., Hassan F.A.S., Elgimabi M. 2018. Improving the growth, yield and volatile oil content of Pelargonium graveolens L. Herit by foliar application with moringa leaf extract through motivating physiological and biochemical parameters. South African Journal of Botany 119: 383-389. DOI: 10.1016/j.sajb.2018.10.003.

Badiyan D., Wills R.B.H., Bowyer M.C. 2004. Use of a nitric oxide donor compound to extend the vase life of cut flowers. HortScience 39: 1371-1372. DOI: 10.21273/hortsci.39.6.1371.

Beligni M.V., Fath A., Bethke P.C., Lamattina L., Jones R.L. 2002. Nitric oxide acts as an anti-oxidant and delays programmed cell death in barley aleurone layers. Plant Physiology 129: 1642-1650. DOI: 10.1104/pp.002337.

Bowyer M.C., Wills R.B.H., Badiyan D., Ku V.V.V. 2003. Extending the postharvest life of carnations with nitric oxide - comparison of fumigation and in vivo delivery. Postharvest Biology and Technology 30: 281-286. DOI: 10.1016/s0925-5214(03)00114-5.

Chang-li Z., Li L., Guo-quan X. 2011. The physiological responses of carnation cut flowers to exogenous nitric oxide. Scientia Horticulturae 127: 424-430. DOI: 10.1016/j.scienta.2010.10.024.

Corpas F.J., Barroso J.B., Carreras A., Valderrama R., Palma J.M., León A.M. et al. 2006. Constitutive arginine-dependent nitric oxide synthase activity in different organs of pea seed-lings during plant development. Planta 224: 246-254. DOI: 10.1007/s00425-005-0205-9.

Cross E. 1996. Safe alternative to STS. Pennsylvania Flower Grower's Bulletin 435: 1-3.

Deng Y., Wang C., Huo J., Hu W., Liao W. 2019. The involvement of $\mathrm{NO}$ in ABA-delayed the senescence of cut roses by maintaining water content and antioxidant enzymes activity. Scientia Horticulturae 247: 35-41. DOI: 10.1016/j.scienta.2018.12.006.

van Doorn W.G., Groenewegen G., van de Pol P.A., Berkholst C.E.M. 1991. Effects of carbohydrate and water status on flower opening of cut Madelon roses. Postharvest Biology and Technology 1: 4757. DOI: 10.1016/0925-5214(91)90018-7.

Eum H.L., Kim H.B., Choi S.B., Lee S.K. 2009. Regulation of ethylene biosynthesis by nitric oxide in tomato (Solanum lycopersicum L.) fruit harvested at different ripening stages. European Food Research and Technology 228: 331-338. DOI: 10.1007/s00217-008-0938-3. 
Giba Z., Grubišić D., Todorović S., Sajc L., Stojaković Đ., Konjević R. 1998. Effect of nitric oxide - releasing compounds on phytochrome - controlled germination of Empress tree seeds. Plant Growth Regulation 26: 175-181. DOI: 10.1023/a:1006131215297.

Hassan F.A.S., Ali E.F. 2014. Protective effects of 1methylcyclopropene and salicylic acid on senescence regulation of gladiolus cut spikes. Scientia Horticulturae 179: 146-152. DOI: 10.1016/j.scienta.2014.09.025.

Hassan F.A.S., Fetouh M.I. 2019. Does moringa leaf extract have preservative effect improving the longevity and postharvest quality of gladiolus cut spikes? Scientia Horticulturae 250: 287-293. DOI: 10.1016/j.scienta.2019.02.059.

Hassan F.A.S., Mahfouz S.A. 2012. Effect of 1-methylcyclopropene (1-MCP) on the postharvest senescence of coriander leaves during storage and its relation to antioxidant enzyme activity. Scientia Horticulturae 141: 69-75. DOI: 10.1016/j.scienta.2012.04.021.

Hassan F., Schmidt G. 2004. Post-harvest characteristics of cut carnations as the result of chemical treatments. Acta Agronomica Hungarica 52(2): 125 132. DOI: 10.1556/aagr.52.2004.2.2.

Hassan F.A.S., Ali E.F., El-Deeb B. 2014. Improvement of postharvest quality of cut rose cv. 'First Red' by biologically synthesized silver nanoparticles. Scientia Horticulturae 179: 340-348. DOI: 10.1016/j.scienta.2014.09.053.

Hassan F.A.S., Mazrou R., Gaber A., Hassan M.M. 2020. Moringa extract preserved the vase life of cut roses through maintaining water relations and enhancing antioxidant machinery. Postharvest Biology and Technology 164; 111156. DOI: 10.1016/j.postharvbio.2020.111156.

Heiser I., Osswald W.F., Elstner E.F. 1998. Photodynamic ethane and ethylene formation from $\alpha$-linolenic acid catalyzed by cytokinins and copper ions. Journal of Plant Physiology 152: 230-234. DOI: 10.1016/s0176-1617(98)80137-5.

Hodges D.M., DeLong J.M., Forney C.F., Prange R.K. 1999. Improving the thiobarbituric acid-reactivesubstances assay for estimating lipid peroxidation in plant tissues containing anthocyanin and other interfering compounds. Planta 207: 604-611. DOI: 10.1007/s004250050524.

Ichimura K., Shimizu-Yumoto H., Goto R. 2009. Ethylene production by gynoecium and receptacle is associated with sepal abscission in cut Delphinium flowers. Postharvest Biology and Technology 52: 267 272. DOI: 10.1016/j.postharvbio.2008.12.008.
In B.C., Strable J., Binder B.M., Falbel T.G., Patterson S.E. 2013. Morphological and molecular characterization of ethylene binding inhibition in carnations. Postharvest Biology and Technology 86: 272-279. DOI: 10.1016/j.postharvbio.2013.07.007.

Kim J.H., Lee A.K., Suh J.K. 2005. Effect of certain pretreatment substances on vase life and physiological characters in Lilium spp. Acta Horticulturae 673: 307-314. DOI: 10.17660/actahortic.2005.673.39.

Ku V.V.V., Wills R.B.H., Leshem Y.Y. 2000. Use of nitric oxide to reduce postharvest water loss from horticultural produce. Journal of Horticultural Science and Biotechnology 75: 268-270. DOI: 10.1080/14620316.2000.11511235.

Leshem Y.Y., Haramaty E. 1996. The characterization and contrasting effects of the nitric oxide free radical in vegetative stress and senescence of Pisum sativum Linn. foliage. Journal of Plant Physiology 148: 258263. DOI: 10.1016/s0176-1617(96)80251-3.

Leshem Y.Y., Pinchasov Y. 2000. Non-invasive photoacoustic spectroscopic determination of relative endogenous nitric oxide and ethylene content stoichiometry during the ripening of strawberries Fragaria anannasa (Duch.) and avocados Persea americana (Mill.). Journal of Experimental Botany 51: 1471-1473. DOI: 10.1093/jexbot/51.349.1471.

Leshem Y.Y., Wills R.B.H. 1998. Harnessing senescence delaying gases nitric oxide and nitrous oxide: a novel approach to postharvest control of fresh horticultural produce. Biologia Plantarum 41: 110. DOI: 10.1023/a:1001779227767.

Li H., Huang X., Li J., Liu J., Joyce D., He S. 2012. Efficacy of nano-silver in alleviating bacteria-related blockage in cut rose cv. Movie Star stems. Postharvest Biology and Technology 74: 36-41. DOI: 10.1016/j.postharvbio.2012.06.013.

Li H., Li H., Liu J., Luo Z., Joyce D., He S. 2017. Nanosilver treatments reduced bacterial colonization and biofilm formation at the stem-ends of cut gladiolus 'Eerde' spikes. Postharvest Biology and Technology 123: 102-111. DOI: 10.1016/j.postharvbio.2016.08.014.

Liao W.B., Zhang M.L., Yu J.H. 2013. Role of nitric oxide in delaying senescence of cut rose flowers and its interaction with ethylene. Scientia Horticulturae 155: 30-38. DOI: 10.1016/j.scienta.2013.03.005.

Liu J., Zhang Z., Li H., Lin X., Lin S., Joyce D.C., He S. 2018. Alleviation of effects of exogenous ethylene on cut 'Master' carnation flowers with nano-silver and silver thiosulfate. Postharvest Biology and Technology 143: 86-91. DOI: 10.1016/j.postharvbio.2018.04.017. 
Mansouri H. 2012. Salicylic acid and sodium nitroprusside improve postharvest life of Chrysanthemums. Scientia Horticulturae 145: 29-33. DOI: 10.1016/j.scienta.2012.07.016.

Mortazavi S.N., Talebi S.F., Naderi R.A., Sharafi Y. 2011. Regulation of ethylene biosynthesis by nitric oxide and thidiazuron during postharvest of rose. Journal of Medicinal Plants Re-search 5: 5177-5183.

Mousavi S.R., Rezaei M. 2011. Nanotechnology in agriculture and food production. Journal of Applied Environmental and Biological Sciences 1: 414-419.

Murphy M.E., Noack E. 1994. Nitric oxide assay using hemoglobin method. Methods in Enzymology 233: 240-250. DOI: 10.1016/s0076-6879(94)33027-1.

Naing A.H., Win N.M., Han J.S., Lim K.B., Kim C.K. 2017. Role of nano-silver and bacterial strain Enterobacter cloacae in increasing vase life of cut carnation 'Omea'. Frontiers in Plant Science 8; 1590; 12 p. DOI: $10.3389 /$ fpls.2017.01590.

Nowak J., Rudnicki R.M. 1990. Postharvest handling and storage of cut flowers, florist greens, and potted plants. Timber Press, pp. 39-43. DOI: 10.1007/97894-009-0425-5.

Onozaki T., Ikeda H., Shibata M. 2004. Video evaluation of ethylene sensitivity after anthesis in carnation (Dianthus caryophyllus L.) flowers. Scientia Horticulturae 99: 187-197. DOI: 10.1016/s03044238(03)00094-3.

Park D.Y., Naing A.H., Ai T.N., Han J.S., Kang I.K, Kim C.K. 2017. Synergistic effect of nano-silver with sucrose on extending vase life of the carnation cv. Edun. Frontiers in Plant Science 8; 1601; 10 p. DOI: 10.3389/fpls.2017.01601.

Pun U.K., Yamada T., Tanase K., Shimizu-Yumoto H., Satoh S., Ichimura K. 2014. Effect of ethanol on ethylene biosynthesis and sensitivity in cut carnation flowers. Postharvest Biology and Technology 98: 30-33. DOI: 10.1016/j.postharvbio.2014.06.018.

Rafi Z.N., Ramezanian A. 2013. Vase life of cut rose cultivars 'Avalanche' and 'Fiesta' as affected by Nano-Silver and S-carvone treatments. South African Journal of Botany 86: 68-72. DOI: 10.1016/j.sajb.2013.02.167.

Reid M.S., Wu M.J. 1992. Ethylene and flower senescence. Plant Growth Regulation 11: 37-43. DOI: 10.1007/bf00024431.

Sairam R.K., Deshmukh P.S., Shukla D.S. 1997. Tolerance to drought and temperature stress in relation to increased antioxidant enzyme activity in wheat. Journal of Agronomy and Crop Science 178: 171177. DOI: 10.1111/j.1439-037x.1997.tb00486.x.
Shabanian S., Esfahani M.N., Karamian R., Tran L.S.P. 2018. Physiological and biochemical modifications by postharvest treatment with sodium nitroprusside extend vase life of cut flowers of two gerbera cultivars. Postharvest Biology and Technology 137: 18. DOI: 10.1016/j.postharvbio.2017.11.009.

Shahri W., Tahir I. 2011. Flower senescence-strategies and some associated events. Botanical Review 77: 152-184. DOI: 10.1007/s12229-011-9063-2.

Sharma V.K., Siskova K.M., Zboril R., Gardea-Torresdey J.L. 2014. Organic coated silver nanoparticles in biological and environmental conditions: Fate, stability and toxicity. Advances in Colloid and Interface Science 204: 15-34. DOI: 10.1016/j.cis.2013.12.002.

Sisler E.C., Dupille E., Serek M. 1996. Effect of 1methylcyclopropene and methylenecyclopropane on ethylene binding and ethylene action on cut carnations. Plant Growth Regulation 18: 79-86. DOI: 10.1007/bf00028491.

Song L.L., Liu H., You Y.L., Sun J., Yi C., Li Y.B. et al. 2014. Quality deterioration of cut carnation flowers involves in antioxidant systems and energy status. Scientia Horticulturae 170: 45-52. DOI: 10.1016/j.scienta.2014.02.035.

Terék O., Mosonyi I., Jámbor-Benczúr E., Hassan F.A.S., Máthé A. 2010. Effect of different treatments on vase life of carnation 'Gioko'. Acta Horticulturae 877: 1757-1762. DOI: 10.17660/actahortic.2010.877.241.

Weatherley P.E. 1950. Studies in the water relations of the cotton plant. I. The field measurement of water deficits in leaves. New Phytologist 49: 81-97. DOI: 10.1111/j.1469-8137.1950.tb05146.x.

Zaharah S.S., Singh Z. 2011. Postharvest nitric oxide fumigation alleviates chilling injury, delays fruit ripening and maintains quality in cold-stored 'Kensington Pride' mango. Postharvest Biology and Technology 60: 202-210. DOI: 10.1016/j.postharvbio.2011.01.011.

Zeng C.L., Liu L., Xu G.G. 2011. The physiological responses of carnation cut flowers to exogenous nitric oxide. Scientia Horticulturae 127: 424-430. DOI: 10.1016/j.scienta.2010.10.024.

Zhu S.H., Zhou J. 2007. Effect of nitric oxide on ethylene production in strawberry fruit during storage. Food Chemistry 100: 1517-1522. DOI: $10.1016 /$ j.foodchem.2005.12.022.

Zottini M., Formentin E., Scattolin M., Carimi F., Lo Schiavo F., Terzi M. 2002. Nitric oxide affects plant mitochondrial functionality in vivo. FEBS Letters 515: 75-78. DOI: 10.1016/s0014-5793(02)02438-9. 